\title{
Prevalence and Possible Surgical Interventionof Ear, Nose and Throat Diseases in Local Population of Pakistan
}

\author{
Muhammad Tariq Rafi', ${ }^{1,3}$, Shafaque Mehboob ${ }^{1}$, Khalid Aftab ${ }^{2 *}$, Zafar Said Saify ${ }^{1}$, Uneeba Rehman ${ }^{3}$ \\ ${ }^{1}$ Jinnah Sindh Medical University, Karachi-Pakistan \\ ${ }^{2}$ Department of Pharmacology and Therapeutics, Islam Medical and Dental College, Sialkot-Pakistan \\ ${ }^{3}$ Jinnah Post Medical College, Karachi-Pakistan
}

*Corresponding author: Khalid Aftab, Department of Pharmacology and Therapeutics, Islam Medical and Dental College, SialkotPakistan. Tel: +923335632975; Email: aftabk@cyber.net.pk

Citation: Rafi MT, Mehboob S, Aftab K, Saify ZS, Rehman U (2017) Prevalence and Possible Surgical Intervention of Ear, Nose and Throat Diseases in Local Population of Pakistan. J Pharma Pharma Sci: JPPS-137. DOI:10.29011/2574-7711/100037

Received Date: 29 July, 2017; Accepted Date: 03 August, 2017; Published Date: 11 August, 2017

\begin{abstract}
Objective: To study the prevalence of ear, nose and throat diseases and their possible surgical intervention in local population of Pakistan.

Methodology: 1,382 patients from the department of ear, nose and throat surgery from January-December 2016 were selected in this retrospective study. The age, gender, presenting complains with history, diagnosis and operative procedures were noted. These patients were divided into three groups according to the involvement of Otorhinolaryngological anatomical region. Analysis of the data was performed using SPSS version 16 and results are expressed in numbers or percentages.

Results: The age ranges of patients were one year to 85 years with maximum age group of $10-19$ years. There were $58.82 \%$ males and $41.46 \%$ were females. Patients with head/ neck diseases were $42.15 \%$, with nasal distress were $29.01 \%$, with ear problems $16.71 \%$ and with oral disorders were $12.22 \%$, therefore, the most commonly adopted methods were removal of tumor/ polyps, tonsillectomy and mastoidectomy.
\end{abstract}

Conclusion: Ear diseases were the most found in the current study and oral cavity lesions being the least common. The peak age was 10-19 years. There is a need of man power and implantation of new techniques.

Keywords: Otorhinolaryngological (ORL) Diseases; Retrospective Study; Prevalence; Surgical; Intervention

\section{Introduction}

Wide varieties of Ear, Nose and Throat diseases and limited facilities are always one of the leading challenges for health care administrators and providers in under developed countries like Pakistan [1-2]. The spectrum of these disorders displays great variation from one community to another be it congenital or acquired [3]. Proper knowledge and treatment/surgical intervention in time may let a patient to lead quality life without social embarrassment and economic losses due to aesthetic problem of the face or comorbidities associated with impairment physiologic functions of hearing and breathing [4]. Ear infection is one of the most prevalent diseases specially in pediatric population and may badly effect the speech development due to conductive and sensorineural hearing loss as well as behavioral responses in children if persist for longer period of time usually caused by Pseudomonas aeruginosa and Staphylococcus aureus [5-11]. Several studies conducted in different parts of the world including Europe and Asian countries reveals the risk factors associated with the middle ear infection strongly correlate this with poor socioeconomic status, improper ventilation, smoking and low birth weight etc. [12-17].

Acute sinusitis may lead to the chronic pathology, if lasts for couple of month with persistent symptoms and signs altering CT scan [18-20]. It is prevalent up to $14 \%$ of the global population in USA but in the case of pediatric patients, the condition is further exaggerated and may reach to $32 \%$. If economic burden is taken under consideration, only in USA 24 million patients received medical aid for the same problem in 1992 that cost \$200 


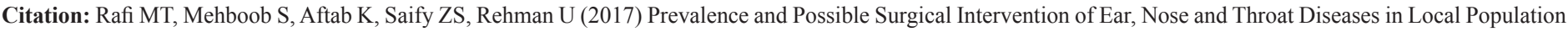
of Pakistan. J Pharma Pharma Sci: JPPS-137.

million. In the case of children less than 8 , rate is much higher [21]. When multivariate analysis was carried out in a study, not only occupational or inheritance factors proved to be affected but some medications such as corticosteroids and local decongestants were also included among risk factors [22-26].

Oral cancer damaging oropharynx cavity arising as the most prevalent type of carcinoma all over the world, having almost the same factors in all populations such as tobacco and alcohol with a new thread of Human Papillomavirus (HPV) including Pakistan involving tonsil, base of the tongue, and other parts of the pharynx [28-34].

The main objective of the current study is to provide a data based information reflecting the magnitude of otalaryngological disorders or distress with the possible surgical management in local population of Pakistanto guide health policy makers of the respective field for the implementation of modifiedplanning.

\section{Patients and Methods}

Inclusion Criteria: patients with chronic signs and symptoms that cannot be managed without surgical intervention, during the period January 2016 to December 2016 with the age 0 to 85 years of both the gender.

Exclusion Criteria: neonates, patients with acute diseases of e.n.t. that can be managed at home, other than 2016 calendar year or having any diseases other than ENT.

This is a retrospective study of patients records in January 2016 to December 2016 conducted in a public tertiary care hospital regarding the type of otorhinolaryngological diseases. All the patients who were admitted in the ear, nose and throat department for surgical intervention met, the inclusion criteria, were included in the study. Demographic data showing age gender and complain of the disease and its durationalong with socioeconomic status of the patients was also taken under consideration. Patients aged between 1-85 years of both the gender belonging to the different parts of the country visited the hospital during the mentioned period.

Statistical analysis was done for the collected data interpretation using descriptive analysis with the help of SPSS version 16.0 statistical software. Results are expressed in numbers or percentages and comparison is discussed among the groups.

\section{Results}

During the study period, as shown in (Table-1\&Figure1)1382 patients admitted in Ear, Nose and Throat (ENT) department (surgical ward) of a tertiary care hospital. Statistical values presented greater percentage of male patients' i.e., $58.82 \%$ as compare to female $41.46 \%$ like many studies conducted in different populations in different part of the world.
The highest percentage of age group $10-19$ up to $27.56 \%$ is alarming situation for parents to protect their children from infections or allergens leading to e.n.t disorders. Although minimum percentage of $1.51 \%$ belong to 70 years or plus patients but the maximum age was of 85 years of two male patients.

\begin{tabular}{|c|c|c|c|c|}
\hline Age in years & $\begin{array}{c}\text { Male } \\
\text { (numbers) }\end{array}$ & $\begin{array}{c}\text { Female } \\
\text { (numbers) }\end{array}$ & $\begin{array}{c}\text { Total Num- } \\
\text { bers }\end{array}$ & $\begin{array}{c}\text { Percentage/ } \\
\text { frequencies of } \\
\text { total (\%) }\end{array}$ \\
\hline $0-9$ & 89 & 67 & 156 & 11.28 \\
\hline $10-19$ & 215 & 166 & 381 & 27.56 \\
\hline $20-29$ & 147 & 108 & 255 & 18.45 \\
\hline $30-39$ & 106 & 86 & 192 & 13.89 \\
\hline $40-49$ & 123 & 75 & 198 & 14.32 \\
\hline $50-59$ & 59 & 38 & 97 & 7.01 \\
\hline $60-69$ & 58 & 28 & 86 & 6.22 \\
\hline $70-$ onward & 16 & 5 & 20 & 1.14 \\
\hline Total \% & $58.82 \%$ & $41.46 \%$ & 1382 & $100 \%$ \\
\hline
\end{tabular}

Table1: Age Distribution of E.N.T disorders.

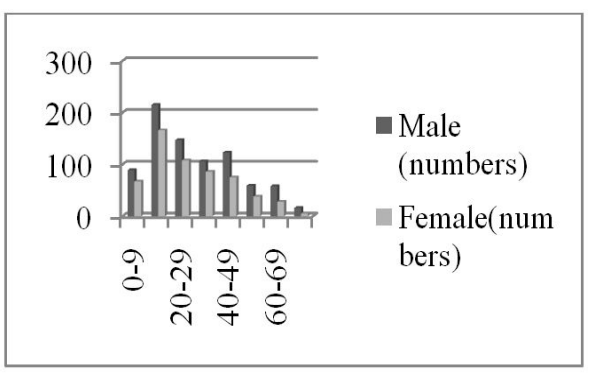

Figure1: Age Distribution of E.N.T disorders.

According to (Table-2 \& Figure-2) most frequently applied surgical technique was with the use of general anesthesia upto $48.98 \%$, then local anesthesia found i.e., 21.56\%, then Fibrotic direct laryngoscopy upto $17.43 \%$ and the least was punch biopsy up to $12.01 \%$.

\begin{tabular}{|c|c|c|}
\hline Technique used & Numbers & Percentage \\
\hline Local anesthesia & 298 & 21.56 \\
\hline General anesthesia & 677 & 48.98 \\
\hline Punch biopsy & 166 & 12.01 \\
\hline $\begin{array}{c}\text { Fiberoptic direct laryn- } \\
\text { goscopy }\end{array}$ & 241 & 17.43 \\
\hline Total Table 2: Adopted Surgical Technique. \\
\hline \multicolumn{2}{|c|}{} \\
\hline
\end{tabular}

If prevalence and surgical management is concerned, most of the patients $(31.04 \%)$ were admitted due to pharyngeal problems, then nasal disorders (29.01\%), after that ear problem (16.71\%), then oral diseases and finally laryngeal disorders (11.11\%) (Table-3 \& Figure-3). 
Citation: Rafi MT, Mehboob S, Aftab K, Saify ZS, Rehman U (2017) Prevalence and Possible Surgical Intervention of Ear, Nose and Throat Diseases in Local Population of Pakistan. J Pharma Pharma Sci: JPPS-137.

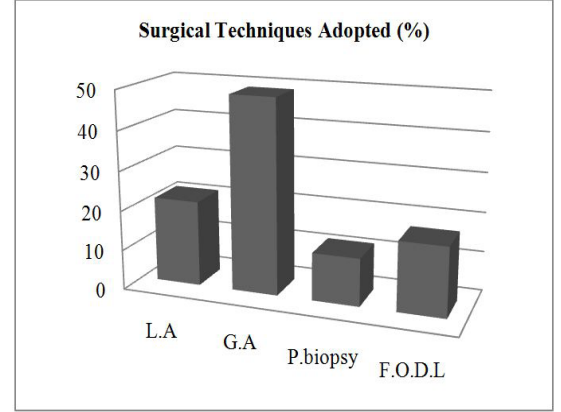

Figure2: Adopted Surgical Technique.

Total 169 patients were admitted due to oral growth or lesion (66), cancer (52), tongue tie (31) and other problems (20). In the case disorders , 231 patients were enrolled among them 144 were due to chronic suppurative otitis media, 40 because of cyst or keloid removal, 35 to get rid of foreign particles and 12 were sufferingother problems.401 patients were facing the disorders of nose in which maximum number was of angiofebroma either with epistaxis (182) or without epistaxis(30), then of deviated nasal septum 91300who underwent septoplasty and the least number of patients with foreign particles for removal, although 16 patients were of different problems.Pharyngealcomplains reflecting the disorders of adenoids (570, tonsillitis (234), stridor (80), cancer (42) and overgrowth in the region (11). In the case of thyroid, 53 cases were reported who subjected to lobectomy. Laryngeal biopsy or removal of carcinogenic area was confirmed in 72 patients.

\begin{tabular}{|c|c|c|c|}
\hline & Anatomical region & $\begin{array}{c}\text { Num- } \\
\text { bers }\end{array}$ & Frequency (\%) \\
\hline \multirow[t]{6}{*}{$\mathbf{A}$} & ORAL & & $\begin{array}{c}12.22 \%(\text { out of } \\
1382)\end{array}$ \\
\hline & Oral growth/lesion & 66 & 9.05 (out of 169 ) \\
\hline & Cancer & 52 & 30.7(out of 169) \\
\hline & Tongue tie & 31 & 18.34 (out of 169 ) \\
\hline & Others & 20 & 11.83 (out of 169) \\
\hline & Total & 169 & \\
\hline \multirow[t]{6}{*}{ B } & EAR & & 16.71(out of 1382) \\
\hline & CSOM /Mastoidectomy & 144 & 62.33 (out of 231) \\
\hline & Cyst /keloid & 40 & $17.31($ out of 231$)$ \\
\hline & F.B & 35 & $14.9($ out of 231$)$ \\
\hline & Others & 12 & $5.19($ out of 231$)$ \\
\hline & Total & 231 & \\
\hline \multirow[t]{5}{*}{$\mathbf{C}$} & NOSE & & 29.01(out of 1382) \\
\hline & $\begin{array}{c}\text { Angiofebroma with } \\
\text { epistaxis }\end{array}$ & 182 & 45.38 (out of 401 ) \\
\hline & D.N.S / Septoplasty & 130 & $32.41($ out of 401$)$ \\
\hline & Nasopharyngeal growth & 30 & $7.48($ out of 401$)$ \\
\hline & F.B & 43 & 10.72 (out of 401 ) \\
\hline
\end{tabular}

\begin{tabular}{|c|c|c|c|}
\hline & OTHERS & 16 & 3.99 (out of 401) \\
\hline & Total & $\mathbf{4 0 1}$ & \\
\hline D & NECK & & $\begin{array}{c}\mathbf{4 2 . 1 5 \% ( o u t ~ o f ~} \\
\text { 1382) }\end{array}$ \\
\hline & PHARYNX & & 31.04 (out of 1382) \\
\hline & Adenoids & 57 & 13.28 (out of 429) \\
\hline & Tonsillitis & 234 & 54.54 (out of 429) \\
\hline & Stridor/ tracheotomy & 80 & 18.6 (out of 429) \\
\hline & Growth & 11 & 2.56 (out of 429) \\
\hline & Vocal cord cancer & 47 & 10.9 (out of 429) \\
\hline & Total & $\mathbf{4 2 9}$ & \\
\hline & LARYNX & & 11.11 (out of 1382) \\
\hline & Lobectomy & 53 & 34.64 (out of 153) \\
\hline & Biopsy/ cancers & 72 & 47.05 (out of 153) \\
\hline & Others & 28 & 18.30 (out of 153) \\
\hline & Total & $\mathbf{1 5 3}$ & \\
\hline
\end{tabular}

Table 3: Ear, Nose and Throat Orders/Surgical Management Distribution.

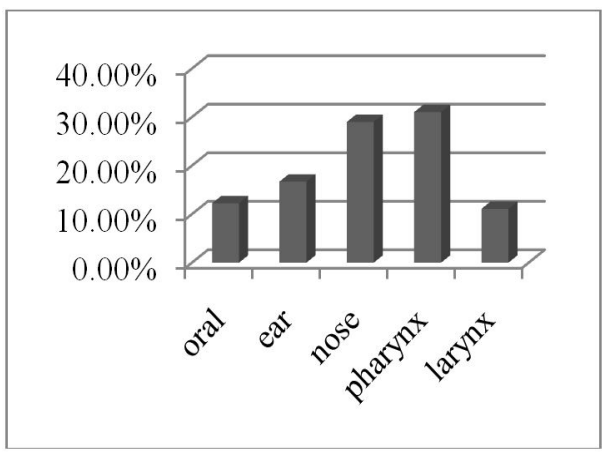

Figure 3: Ear, Nose and Throat Orders/Surgical Management Distribution Discussion.

The provided data of e.n.t. diseases of the whole mentionedyear in the current study reflect not just the spectrum of otalaryngological distress but in-depth of surgical interventions using different techniques too. These heavy expensesnot only due to recurrent and metastatic conditions but even because of presence of foreign particles in nasal, ear or airway path is an alarming situation for the parents, health establishments and also for general public to launch awareness programs and better policies [28].

There were more male patients as compare to the female who admitted the ward to seek aid and the maximum of teenage. Most of the cases strongly correlate to the socio-economic status and tropical region of the patients. This study is agreed with the research conducted by A. J FasunlaM. Samdiand O. G. Nwaorgu [36]. As far as combined cases of pharynx and larynx are considered, it contributes the maximum $42.15 \%$ of the total which is huge, among them tonsillitis aroused as the most common. 
Citation: Rafi MT, Mehboob S, Aftab K, Saify ZS, Rehman U (2017) Prevalence and Possible Surgical Intervention of Ear, Nose and Throat Diseases in Local Population of Pakistan. J Pharma Pharma Sci: JPPS-137.

Irrespective to the anatomical site, if only local aggressive vascular tumor (be it benign or malignant) plus biopsy for its confirmation is focused, 499 out of 1382 constitute $32.48 \%$ of the whole year e.n.t incidences. In several evidence based research articles ear diseases usually infections are reported maximum among the e.n.t. distress but unfortunately in our population gutka chewing is found to exaggerate the prevalence of squamous cell carcinoma which is already accounting the head and neck malignancy at the highest level [35].

80 patients with Strider underwent tracheostomy for proper and safe mechanical ventilation. In addition to this, 53 patients, suffering from cold nodules were subjected to lobectomy from different parts of the country once again focusing our attention to provide clean and safe water to nip in the bud of this disease cause. Out of 401 patients from nasal disorders, 182 got angiofebroma with epistaxis and 30 without it. Septoplasty was the most commonly employed method for deviated nasal septum.

Chronic superlative otitis media was the leading ear diseases which affected 144 patients. Usually in first decade of life, ear infections badly influence life style but if it is left untreated, second decade become worsen due to this chronic infection or may be because of its late consequences such as hear loss or throat or nasal obstructions [36]. It's time to establish public speciallyparents awareness programs such as neonatal early hearing diagnosis and rehabilitation programs to save our energy, economy and the most importantly people.

\section{References}

1. Martin JAM (1967) Diseases of the ear, nose and throat in tropical Africa. A Uganda survey. Journal of Laryngology and otology 81: 10791098.

2. Ibekwe TS,Nwaorgu OGB, Onakoya PA, Ibekwe PU (2005) Spectrum of Otorhinolaryngological emergencies in elderly in Ibadan, Nigeria. Nig J Med14: 411-414.

3. Kishve SP, Kumar N, Kishve PS, Aarif SMM, Kalakoti P (2010) Ear, Nose and Throat disorders in paediatric patients at a rural hospital in India. Australasian Medical Journal AMJ 3: 786-790.

4. Famuyiwa OO,Olorunshola DA, Derin A (1998) Some family factors in sickle cell anemia in Lagos, Nigeria. Nig Med Practitioner 35:70-73.

5. Roberts JE, Rosenfeld RM,Zeisel SA (2004)Otitis media and speech and language: a meta-analysis of prospective studies. Pediatrics113: 238-248.

6. Thorne JA (2003)Middle ear problems in Aboriginal school children cause developmental and educational concerns. Contemporary Nurse 16: $145-150$.

7. Zinkus PW, Gottlieb MI,Schapiro M (1978) "Developmental and psychoeducational sequelae of chronic otitis media. American Journal of Diseases of Children 132: 1100-1104.
8. Baumann B, Gerendas PK, Plinkert, Praetorius M (2011) General and disease-specific quality of life in patients with chronic suppurative otitis media-a prospective study. Health and Quality of Life Outcomes 29: 9-48.

9. Brouwer CNM, Maillé AR, Rovers MM, Grobbee, Sanders EAM, et al. (2005) Health-related quality of life in children with otitis media. International Journal of Pediatric Otorhinolaryngology 69: 1031-1041.

10. Yiengprugsawan $V$, Hogan $A$,Strazdins $L$ (2013) Longitudinal analysis of ear infection and hearing impairment: findings from 6-year prospective cohorts of Australian children. BMC Pediatrics 13: 28.

11. Hogan M, Shipley L, Strazdins A, Purcell, Baker E (2011)Communication and behavioural disorders among children with hearing loss increases risk of mental health disorders. Australian and New Zealand Journal of Public Health 35: 377-383.

12. Dhooge JM (2003) Risk factors for the development of otitis media. Current Allergy and Asthma Reports, View at Google Scholar. View at Scopus 4: 321-325

13. Rovers MM, de Kok IMCM, Schilder AGM (2006) Risk factors for otitis media: an international perspective. International Journal of Pediatric Otorhinolaryngology 70: 1251-256.

14. Hetzner NMP, Razza RA, Malone LM,Brooks-Gunn J (2009) Associations among feeding behaviors during infancy and child illness at two years. Maternal and Child Health Journal 13: 795-805.

15. Morrissey TW (2012) Multiple child care arrangements and common communicable illnesses in children aged 3 to 54 months. Maternal and Child Health Journal 17: 1175-1184.

16. Maclntyre EA,Karr CJ, Koehoorn M, Demers P, Tamburic L,et al. (2010) Otitis media incidence and risk factors in a population-based birth cohort. Paediatrics and Child Health 15: 437-442.

17. Kong K, Coates HLC (2009)Natural history, definitions, risk factors and burden of otitis media. Medical Journal of Australia191: S39-S43.

18. Lund VJ, Kennedy DW (1995) Quantification for staging sinusitis. The Staging and Therapy Group. Ann Otol Rhinol Laryngol Suppl 167: 17-21.

19. Clement PAR, Bluestone CD, Gordts F, Lusk RP, Otten FW, et al. (1998) Management of rhinosinusitis in children. Consensus Meeting, Brussels, 13 September 1996. Arch Otolaryngol Head Neck Surg 124: 31-34.

20. Gwaltney JM, Philipps CD, Miller RD, Riker DK (1994) Computed tomography study of the common cold. N Engl J Med 330: 25-30.

21. DeGroot RRM, Zanten VME (1993) Otorhinolaryngology in outline 1984-1993. SIG Health Care Information, Utrecht: 1-24.

22. Kaliner MA, Osquthorpe JD, Fireman P, Anon J, et al. (1997)Sinusitis: bench to bedside. Otolaryngol Head Neck Surg 100: 510.

23. BerendesJ, Link JR, Zöllner FAlbegger KW, Banale Entzüngender Nase under Nasenbenhölen. In: Hals, Nasen-, Ohren Heilkunde in Praxis und Klinik. Band I. Obere und untere Luftwege. eds Berendes J, Link JR, Zöllner F, G Thieme Verlag, Stuttgart: 11.1-11.32.

24. Kennedy DW (1994)Sinus diseases: guide to first-line management. Health Communications, Deerfield Beach, Florida: 12. 
Citation: Rafi MT, Mehboob S, Aftab K, Saify ZS, Rehman U (2017) Prevalence and Possible Surgical Intervention of Ear, Nose and Throat Diseases in Local Population of Pakistan. J Pharma Pharma Sci: JPPS-137.

25. Beauvillain de Montreuil C, AubertP, PerahiaM, et al.(1998) Facteurs de risque de sinusitechronique. J Franç ORL 47: 261-264.

26. Savolainen S (1989) Allergy in patients with acute maxillary sinusitis. Allergy 44: 116-122.

27. Porter JP, Patel AA, Dewey CM, Stewart MG (1999)Prevalence of sinonasal symptoms in patients with HIV infection. Am J Rhinol 13:203208.

28. Ferlay J, Shin HR, Bray F, Forman D, Mathers C, etal. (2010) Estimates of worldwide burden of cancer in 2008: Globocan 2008. Int J Cancer 127: 2893-2917.

29. Blot WJ, McLaughlin JK, Winn DM, Austin DF, Greenberg RS, et al. (1988) Smoking and drinking in relation to oral and pharyngeal cancer. Cancer Res 48: 3282-3287.

30. Hashibe M, Brennan P, Benhamou S, Castellsague X, Chen C, etal. (2007) Alcohol drinking in never users of tobacco, cigarette smoking in never drinkers, and the risk of head and neck cancer: Pooled analysis in the International Head and Neck Cancer Epidemiology Consortium. J Natl Cancer Inst 99: 777-789.

31. D'Souza G, Kreimer AR, Viscidi R, Pawlita M, Fakhry C, etal. (2007) Case-control study of human papillomavirus and oropharyngeal cancer. N Engl J Med 356: 1944-1956.
32. Gillison ML, Koch WM, Capone RB, Spafford M, Westra WH, et al. (2000) Evidence for a causal association between human papillomavirus and a subset of head and neck cancers. J Natl Cancer Inst 92: 709-720.

33. De Martel C, Ferlay J, Franceschi S, Vignat J, Bray F, etal. (2012) Global burden of cancers attributable to infections in 2008: A review and synthetic analysis. Lancet Oncol 13: 607-615.

34. Lingen MW, Xiao W, Schmitt A, Jiang B, Pickard R, etal. (2013) Low etiologic fraction for high-risk human papillomavirus in oral cavity squamous cell carcinomas. Oral Oncol 49: 1-8.

35. Baig S, Lucky MH, Qamar A, Ahmad F, Khan S, et al. (2012) Human Papilloma Virus and Oral Lesions in Gutka Eating Subjects in Karachi. Journal of the College of Physicians and Surgeons Pakistan 22: 135138.

36. Fasunla AJ, SamdiM, Nwaorgu OG (2013) An audit of Ear, Nose and Throat diseases in a tertiary health institution in South-western Nigeria. Pan Afr Med J 4: 1. 